\title{
PENGARUH SIKAP GURU TERHADAP MOTIVASI BELAJAR SISWA DALAM PEMBELAJARAN ONLINE DI MI BUSTANUL ULUM JEMBER
}

\author{
Robi'ah Al Adawiyah ${ }^{1}$, Shanggita Dewi ${ }^{2}$ \\ IAIN Jember,Prodi Tadris Biologi, Jl. Mataram No.1 Mangli Jember, Jawa Timur Indonesia \\ e-mail: roby46471@gmail.com
}

\begin{abstract}
In online learning is very much needed teacher knowledge about the rules of learning strategy because it is very influential on learning outcomes. Good teacher knowledge allows them to make learning preparations. This research aims to find out students' responses to online learning at home and how to develop the right solutions to create effective online learning. In order for national education goals to be achieved even if learning is limited. The method of data collection used in this study is to use the questionnaire method. Researchers used 30 respondents at Madrasah ibtidaiyah Bustanul ulum Jember as samples. The process of disseminating the questionnaire was done by administering the questionnaire to elementary school children in the researcher's environment through wathsaap private chat using self-Administered Questionnaires technique.The conclusion that can be drawn from this study is that the role of teachers towards the motivation of students' learning is very maintained, where effective learning strategies in this online learning system can produce a good performance energy response for students.
\end{abstract}

Keywords: Teacher Attitude, Motivation to learn, Online learning

ABSTRAK

Dalam pembelajaran online ini sangat di butuhkan pengetahuan guru tentang aturan strategi pembelajaran karena sangat berpengaruh terhadap hasil belajar. Pengetahuan guru yang baik memungkinkan mereka untuk membuat persiapan pembelajaran. Penelitian ini bertujuan untuk mengetahui respons siswa terhadap pemebelajaran online dirumah dan bagaimana menenemukan solusi yang tepat untuk dapat menciptakan pembelajaran online yang efektif. Agar tujuan pendidikan nasional dapat tercapai walau pembelajaran terbatas. Metode pengumpulan data yang digunakan dalam penelitian ini adalah menggunakan metode kuesioner. Peneliti menggunakan 30 responden di madrasah ibtidaiyah bustanul ulum Jember sebagai sampel. Proses penyebarannya kuesioner dilakukan dengan memberikan kuesioner kepada anak sekolah dasar di lingkungan peneliti tersebut melalui chat pribadi wathsaap dengan menggunakan teknik self-Administered Questionnaires. Kesimpulan yang dapat di tarik dari penelitian ini adalah di mana peran sikap guru terhadap motivasi belajar siswa sangat berpengarauh, dimana strategi pembelajaran yang efektif dalam sistem pembelajaran online ini dapat menghasilkan respon energi prestasi yang baik bagi siswa.

Kata Kunci: Sikap Guru, Motivasi belajar, Pembelajaran online 


\section{PENDAHULUAN}

Prinsip Tujuan pendidikan terdapat dalam batang tubuh pembukaan undang-undang dasar 1945 yakni "mencerdaskan kehidupan bangsa". Kemudian diperinci dan diperjelas dalam Undang Undang No. 20 Tahun 2003 pasal tiga menjelaskan bahwa pendidikan nasional berfungsi mengembangkan kemampuan dan membentuk watak serta aturan peradaban bangsa yang bermartabat dalam rangka mencerdaskan kehidupan bangsa. Untuk itu,pendidikan nasional bertujuan untuk mengembangkan potensi peserta didik agar menjadi manusia yang beriman dan bertakwa kepada Tuhan yang Maha esa, berakhlak mulia, sehat, berilmu, cakap, kreatif, mandiri, dan menjadi warga negara yang demokratis serta bertanggung jawab (Mulyasa, 2013: 20) ${ }^{1}$

Profesi guru berhubungan dengan anak didik, yang secara alami mempunyai persamaan dan perbedaan. Tugas melayani orang yang beragam sangat memerlukan kesabaran dan ketelatenan yang tinggi, terutama bila berhubungan dengan peserta didik yang masih kecil. Barangkali tidak semua orang dikarunia sifat seperti itu, namun bila seseorang telah memilih untuk memasuki profesi guru, ia dituntut untuk belajar dan berlaku seperti itu.

Menurut PP No. 74 Tahun 2008 tentang Guru Pasal 1, guru adalah pendidik profesional dengan tugas utama mendidik, mengajar, membimbing, mengarahkan, melatih, menilai, dan mengevaluasi peserta didik pada pendidikan anak usia dini jalur pendidikan formal, pendidikan dasar, dan pendidikan menengah. Berdasarkan beberapa pengertian di atas ditambah dengan pendapat para ahli, dapat ditarik kesimpulan bahwa sikap profesional guru adalah suatu kepribadian atau respon yang menggambarkan kecenderungan untuk bereaksi sebagai seorang guru yang memiliki kompetensi yang dipersyaratkan untuk melakukan tugas pendidikan dan pembelajaran yang ahli dalam menyampaikannya. ${ }^{2}$

Pada Masa pandemi ini pembelajaran terpaksa dilakukan melalui media elektronik atau bisa di sebut pembelajaran online dengan tujuan untuk memutus rantai penyebaran covid-19. Dampak pandemi korona telah merambah ke dunia pendidikan, pemerintah pusat hingga daerah, maka pemerintah memberikan kebijakan untuk menghentikan pembelajaran secara tatap muka dan diganti dengan pembelajaran online bagi seluruh lembaga pendidikan. Hal ini dilakukan sebagai upaya mencegah meluasnya penularan virus korona. Diharapakan dengan seluruh lembaga pendidikan tidak melaksanakan aktivitas seperti biasanya, hal ini dapat meminimalisir menyebarnya penyakit covid 19 ini. Hal serupa juga sudah dilakukan oleh berbagai negara yang terpapar penyakit covid 19 ini, kebijakan lockdown atau karantina dilakukan sebagai upaya

\footnotetext{
${ }^{1}$ Mulyasa.. Pengembangan dan Implementasi Kurikulum 2013. (Bandung: PT. Rosda Karya. 2013)hlm 20

${ }^{2}$ Imron fauzi,Etika profesi keguruan (jember IAIN press, 2017),hlm 243
} 
mengurangi interaksi banyak orang yang dapat memberi akses pada penyebaran virus korona.(Agus purwanto, 2020:3) $)^{3}$

Dalam pembelajaran online ini sangat di butuhkan pengetahuan dan sikap guru tentang aturan strategi pembelajaran karena sangat berpengaruh terhadap hasil belajar. Imron (2017:242) Mengemukakan sikap profesional guru adalah suatu kepribadian atau respon seorang guru yang memiliki kompetensi yang dipersyaratkan untuk melakukan tugas pendidikan dan pembelajaran yang ahli dalam menyampaikannya, menggambarkan kecenderungan untuk bereaksi sebagai pendidik yang profesional. ${ }^{4}$ Pengetahuan guru yang baik memungkinkan mereka untuk membuat persiapan pembelajaran. Mereka mempersiapkan perangkat pembelajaran seperti rencana kegiatan semesteran, mingguan dan harian. Selain itu guru-guru juga membuat media pembelajaran sesuai dengan tema dan subtema aturan yang direncanakan.Persiapan pembelajaran tersebut memungkinkan anak siap untuk mengikuti pembelajaran berikutnya dengan terlebih dahulu mendapatkan pembelajaran sebelumnya. Hal ini untuk memudahkan anak menghubungkan kepada struktur kegiatan pembelajaran secara menyeluruh.(Dandan suryana,2013:199) ${ }^{5}$

Pembelajaran daring memiliki plus minus nya sendiri dalam pelaksanaannya antara lain Pertama, sistem daring memudahkan pembelajaran karena tidak terikat akan tempat dan waktu, tetapi perlu persiapan jauh hari semua perangkat dan bahan, termasuk kurikulumnya. Sedangkan selama ini persiapan pembelajaran menggunakan sitem daring belum ada, sehingga pembelajaran daring hanya diperuntukkan pendidikan guru dalam jabatan, sehingga baik guru maupun masyarakat mengalami guncangan teknologi. Kedua, pembelajaran sistem daring yang memerlukan perangkat teknologi seperti gadget menjadi persoalan bagi satu keluarga apabila memiliki sejumlah anak yang tersebar di semua jenjang pendidikan, sementara penghasilan keluarga terbatas. Maka dari itu, pastinya sistem daring akan sangat memberatkan. Subsidi melalui bebas kuota bagi keluarga seperti ini sangat membantu mereka. Ketiga, kurikulum yang ada secara nasional disiapkan untuk sistem pembelajaran konvensional. Dengan diberlakukannya sistem pembelajaran daring ini secara mendadak pastinya akan timbul beberapa masalah.

Persoalan dalam pembelajaran online bukan hanya menitik beratkan teknologi saja namun persoalan lain juga muncul seperti kurangnya motivasi belajar siswa dikarenakan kurangnya interaksi individu dengan lingkungannya. Ali (1983: 14) mengemukakan bahwa belajar adalah "proses perubahan perilaku, akibat interaksi individu dengan lingkungan". Menurut Sardiman

\footnotetext{
${ }^{3}$ Agus Purwanto, Masduki Asbari, Mochammad Fahlevi, Abdul Mufid, Eva Agistiawati, Yoyok Cahyono, Popong Suryani. (). "Impact of Work From Home (WFH) on Indonesian Teachers Performance During the Covid-19 Pandemic : An Exploratory Study”. International Journal of Advanced Science and Technology,2020, 29(05), 6235 - 6244,

${ }^{4}$ Imron fauzi,Etika profesi keguruan (jember IAIN press, 2017),hlm 242

5 Dadan Suryana.. Pengetahuan Tentang Strategi Pembelajaran, Sikap, Dan Motivasi Guru. Jurnal Ilmu Pendidikan. (Padang: Universitas Negeri Padang,2013).hlm 199. Jilid 19. No. 2.
} 
(1986:22) "Belajar dalam arti luas, dapat diartikan sebagai kegiatan psiko-fisik menunjukkan perkembangan pribadi seutuhnya". Di sini dapat dilihat bahwa belajar merupakan sarana pengembangan pribadi dari individu yang melakukannya. ${ }^{6}$ Lebih lanjut Sardiman (1986:22) juga mendefinisikan belajar dalam arti sempit yaitu "Belajar dimaksudkan sebagai usaha penguasaan materi ilmu pengetahuan yang merupakan sebagai kegiatan menuju terbentuknya kepribadian seutuhnya". Dari pendefinisian tersebut, dapat diartikan bahwa belajar adalah suatu usaha pengembangan diri. $^{7}$

Motivasi yang dianggap sebagai inspirasi yang menggerakkan dan mengarahkan prilaku manusia termasuk prilaku belajar. Dalam motivasi terkandung adanya keinginan, harapan, tujuan, sasaran, dan insentif. Keadaan inilah yang mengaktifkan, menggerakkan, menyalurkan, dan mengarahkan sikap dan prilaku individu belajar. Dengan permasalahan menurunnya motivasi belajar siswa ini maka guru harus dapat pandai menyikapi perilaku siswa dengan meyusun strategi pembelajaran yang dapat membangun motivasi siswa walaupun interaksi dalam pembelajaran sangat minim. Sikap sebagai derajat afek positif atau afek negatif terhadap suatu objek psikologis (Azwar, 2010). ${ }^{8}$ Lebih lanjut Thurstone menjelaskan bahwa sikap merupakan sebuah proses antara positif atau negatif yang disebabkan oleh suatu stimulus. Dengan ini keberhasilan pembelajaran anak sangat bergantung oleh sikap guru dalam pembelajaran.

Penelitian ini bertujuan untuk mengetahui respons siswa terhadap pemebelajaran online dirumah dan bagaimana menenemukan solusi yang tepat untuk dapat menciptakan pembelajaran online yang efektif. Agar tujuan pendidikan nasional dapat tercapai walau pembelajaran terbatas.

\section{METODE}

Bagian Penelitian ini menggunakan data primer. Data primer adalah informasi yang diperoleh secara langsung oleh peneliti sesuai dengan faktor atau fariebel yang dibutuhkan dalam penelian. Data dalam penelitian ini diperoleh dengan membagikan kuesioner kepada koresponden anak sekolah dasar di lingkungan rumah peneliti.

Metode pengumpulan data yang digunakan dalam penelitian ini adalah menggunakan metode kuesioner. Peneliti menggunakan 30 responden di Madrasah Ibtidaiyah Bustanul ulum jember sebagai sampel. Proses penyebarannya kuesioner dilakukan dengan memeberikan kuesioner kepada anak sekolah dasar di lingkungan peneliti tersebut melalui chat pribadi wathsaap dengan menggunakan teknik self-Administered Questionnaires. Teknik self-Administered Questionnaires merupakan metode pengumpulan data yang mencakup wilayah tertentu sehingga memudahkan

\footnotetext{
${ }^{6}$ M Ali. Guru dalam Proses Belajar Mengajar. Bandung: Sinar Baru Algesindo,1983. Hlm 14

${ }^{7}$ A. M.,Sardiman.. Interaksi dan Motivasi Belajar dan Mengajar. (Jakarta: Raja Grafindo Persada,1986) hlm 22

${ }^{8}$ Saifuddin Azwar,.. Metode Penelitian. (Yogyakarta: Pustaka Pelajar,2010)
} 
peneliti dalam mengumpulkan semua data yang diperlukan dengan waktu yang relatif singkat (Sekaran \& Bougie, 2013:147). ${ }^{9}$

\section{HASIL DAN PEMBAHASAN}

Sejatinya belajar dikonotasikan dengan perubahan tingkah laku (perubahan perilaku).WS Winkel (1989: 6) ${ }^{10}$ memberikan pemahaman perubahan sebagai bentuk diri seseorang yang dinyatakan dalam cara-cara bertingkah laku aturan baru, akibat pengalaman dan latihan sejalan itu, Cronbach (1954: 45) mengemukakan bahwa "belajar ditunjukkan oleh perubahan dan perilaku pengalaman". ${ }^{11}$ Buchori ( 1983: 3) Belajar adalah suatu proses perubahan dalam seseorang dimanifestasikan dalam perubahan penguasan pola-pola respon tingkah laku rule baru dan nyata dalam perubahan keterampilan, kebiasaan, kesanggupan dan sikap ${ }^{12}$.Selain itu Reber (Muhibbin Syah, 1995: 90) mengemukakan bahwa belajar pertama adalah metode data, yakni proses memperoleh pengetahuan. ${ }^{13}$

Sedangkan guru sebagai pendidik merupakan perwujudan diri dengan seluruh keunikan karakteristik yang sesuai dengan posisinya sebagai pemangku profesi keguruan. Kepribadian merupakan landasan utama bagi perwujudan diri sebagai guru yang efektif baik dalam melaksanakan tugas profesionalnya di lingkungan pendidikan dan di lingkungan kehidupan lainnya. Hal ini mengandung makna bahwa seorang guru harus mampu mewujudkan pribadi yang efektif untuk dapat melaksanakan fungsi dan tanggung jawabnya sebagai guru. Untuk itu, ia harus mengenal dirinya sendiri dan mampu mengembangkannya ke arah terwujudnya pribadi yang sehat dan paripurna (fully functioning person)..$^{14}$

\footnotetext{
${ }^{9}$ Bougie, dan Sekaren.. Edisi 5, Research Metodhs For Business: A Skill Building Approach. New York: John wiley@Sons. 2013

${ }^{10}$ W.S.Winkel,. Psikologi Penddidikan dan Evaluasi Belajar. (Jakarta: Gramedia,1989.) hlm 6

${ }^{11}$ Conbach Lee J,.. Educational Psychology. BRACE AND COMPANY, (New York: HARCOURT,1954). hlm 45

${ }^{12}$ Buchori..Tehnik-Tehnik Evaluasi Dalam Pendidikan. (Jakarta: Jakarta Djambatan,1983). hlm 3

${ }^{13}$ Muhibbin, Syah.. Psikologi Pendidikan . (Bandung: Remadja Rosda Karya,1995).hlm 90

${ }^{14}$ Imron fauzi,Etika profesi keguruan (jember IAIN press, 2017),hlm 150
} 

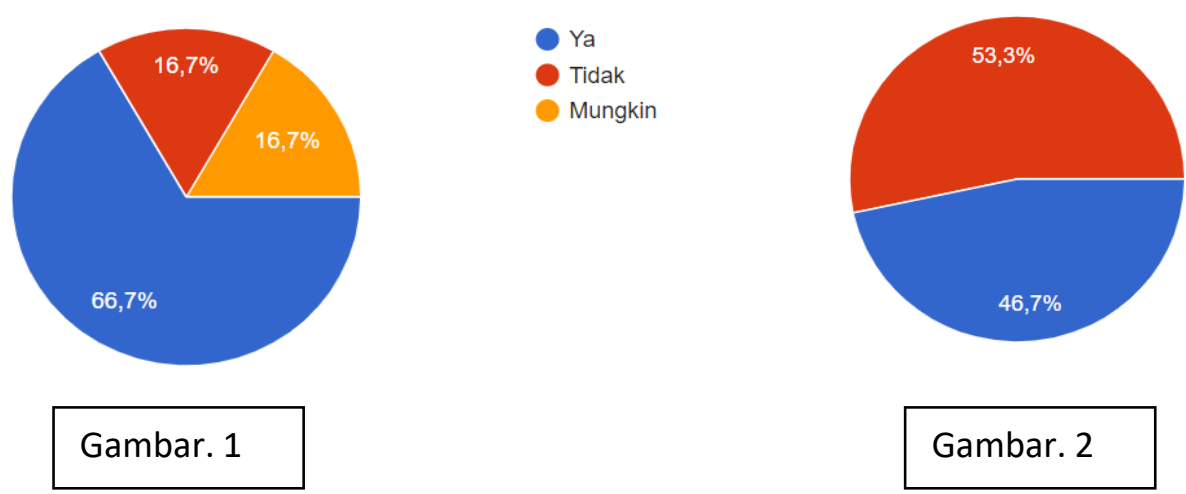

\section{Presentase Berdasarkan Pemahaman Materi yang Disampaikan Guru}

Hasil dari 30 responden sebanyak 66,7\% tidak paham materi yang disampaikan guru dalam pembelajaran online. 16,7\% responden paham materi yang disampaikan dan $16,7 \%$ responden mungkin paham materi yang disampaikan guru dalam pembelajaran online (Gambar 1). Hal ini berarti dalam pembelajaran online pelajar kesulitan dalam memahami materi yang disampaikan oleh guru.Dampak yang dirasakan siswa pada proses belajar mengajar di rumah adalah para siswa merasa dipakasa belajar jarak jauh tanpa sarana dan prasarana yang memadai di rumah. Pembelajaran online di rumah seharusnya disediakan terlebih dahulu fasilitas seperti laptop, komputer ataupun hand phone yang akan memudahkan siswa untuk mengikuti proses belajar mengajar secara online. Kendala selanjutnya yaitu sebelumnya belum ada budaya belajar jarak jauh karena selama ini sistem belajar dilaksanakan melalui tatap muka, siswa terbiasa berada di sekolah untuk berinteraksi, bermain dan bercanda gurau dengan teman-temannya serta bertatap muka dengan para guru. Sehingga ketika guru memberi tugas sebanyak 53,3\% responden (pelajar) yang kesulitan dalam mengerjakan tugas dan $46,7 \%$ responden yang tidak mengalami kesulitan saat diberikan tugas oleh guru. (Gambar 2.) Dengan adanya metode pembelajaran jarak jauh siswa memerlukan waktu untuk beradaptasi dan menghadapi perubahan baru yang secara tidak langsung mempengaruhi daya serap belajar mereka.(Agus purwanto ,Dkk,2020:5) ${ }^{15}$

Peran Guru dalam memotivasi Siswa dalam proses pembelajaran Pada diri setiap manusia telah tersedia menjadi potensi energi atau sebuah kekuatan yang dapat menggerakkan dan mengarahkan tingkah lakunya pada tujuan. Di dalamnya tercakup pula potensi energi/kekuatan untuk berprestasi yang kekuatannya berbeda pada setiap manusia. Apabila terpicu, keadaan ini akan

\footnotetext{
${ }^{15}$ Agus Purwanto, Masduki Asbari, Mochammad Fahlevi, Abdul Mufid, Eva Agistiawati, Yoyok Cahyono, Popong Suryani. (). "Impact of Work From Home (WFH) on Indonesian Teachers Performance During the Covid-19 Pandemic : An Exploratory Study”. International Journal of Advanced Science and Technology,2020, 29(05), 6235 - 6244.
} 
meningkatkan potensi energi untuk berprestasi bahkan akan menggerakkan dan mengarahkan pada tingkah laku belajar. Dengan demikian hal ini dapat memberikan pandangan sekaligus harapan bagi para pendidik/guru bahwa:

1. Setiap diri anak didik/siswa telah dibekali kekuatan untuk berprestasi.

2. Setiap siswa memiliki kekuatan berprestasi berbeda-beda.

3. Setiap siswa dapat meningkatkan prestasi

4. Setiap siswa dapat menunjukkan tingkah laku belajar atau usaha-usaha untuk mencapai tujuan belajar.

5. Guru perlu lebih menghayati perannya sebagai pendidik sehingga muncul rasa tanggung jawab dan kepercayaan diri dalam memproses anak didik.

6. Guru membutuhkan strategi yang dapat memicu bergeraknya motivasi berprestasi setiap siswa.

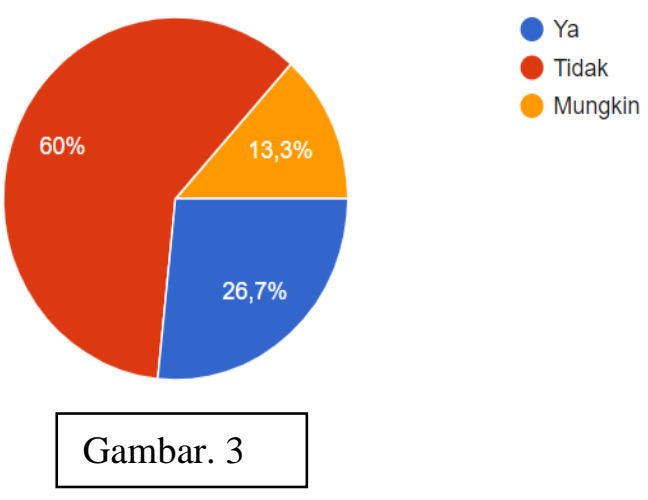

\section{Presentase Berdasarkan Pembelajaran Online Meningkatkan Motivasi Pelajar}

Berdasarkan data diatas didapatkan hasil sebanyak $60 \%$ responden merasa adanya pembelajaran online tidak meningkatkan motivasi. 26,7\% responden merasa termotivasi dengan adanya pembelajaran online dan sisanya yaitu 13,3\% responden mungkin dengan adanya pembelajaran online motivasi belajarnya meningkat (Gambar 3). Dari hasil diatas peneliti menyimpulkan bahwa pembelajaran online tidak meningkatkan motivasi belajar responden. Sehingga sikap dan peran guru sangat penting untuk keberhasilan pembelajaran online. Dalam proses pembelajaran, motivasi adalah salah satu aspek dinamis yang sangat penting. peserta didik yang kurang berprestasi sering kali bukan disebabkan oleh kemampuannya yang kurang, tetapi karena tidak adanya motivasi untuk belajar sehingga ia tidak berusaha untuk mengerahkan segala kemampuannya. Peran sikap guru terhadap kemauan dan motivasi belajar siswa sangat penting. Dalam memulai dan memelihara usaha siswa, motivasi memandu dalam pengambilan keputusan, 
dan kemauan menopang kehendak untuk menyelami suatu tugas sedemikian sehingga tujuan dapat dicapai.( Ahmad Idzhar,2016) ${ }^{16}$
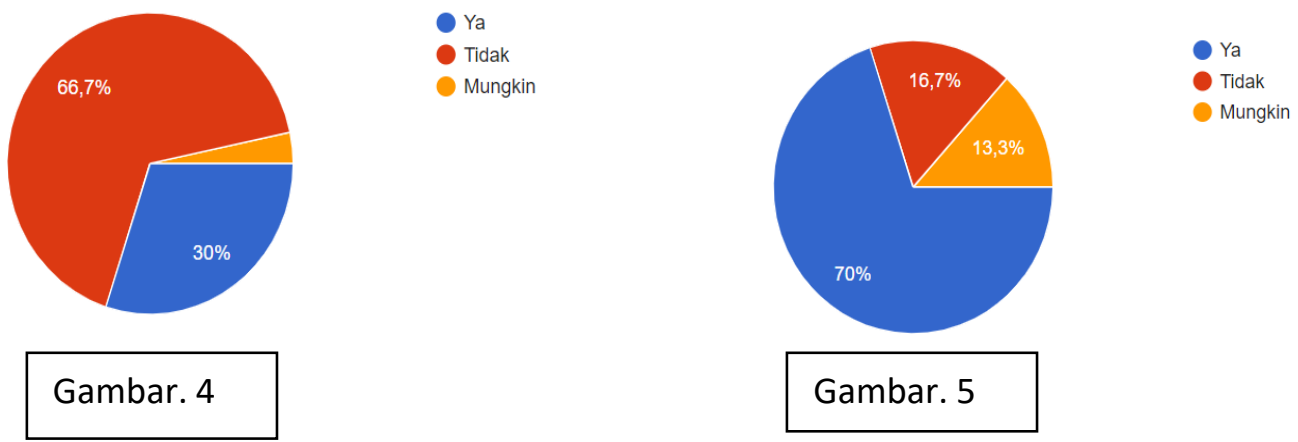

\section{Diagram Presentase Berdasarkan Akses Dan Minat Pembelajaran Online}

Dari data diatas peneliti menyimpulkan bahwa 66,7\% responden tidak berminat dalam pembelajaran online. Kemudian $30 \%$ responden yang minat dalam pembelajaran online dan 3,3\% yang mungkin berminat dalam pembelajar online (Gambar 4). Ini artinya responden banyak yang kurang berminat dalam pembelajaran online. Sedangkan Pada (Gambar 5) presentase akses yang dimiliki responden dalam pembelajaran online didapatkan hasil $70 \%$ responden memiliki akses untuk pembelajaran online. Sebanyak 16,7\% responden tidak memiliki akses untuk pembelajaran online dan 13,3\% responden yang mungkin memiliki akses untuk pembelajaran online. Dapat disimpulkan bahwa pembelajaran online kurang diminati oleh responden meskipun responden memiliki akses untuk melaksanakan pembelajaran secara online.dari hasil presentase ini menimbulkan saran perbaikan dalam berbagai aspek untuk pembelajaran online yang sering berhubungan dengan ketidakpuasan siswa. Sebagai contoh, siswa menyarankan perbaikan di sekitar bidang ketidakpuasan seperti meningkatkan ketidak stabilan jaringan, mengaktifkan interaksi, dan melakukan latihan kelas tatap muka. Ketidakpuasan terbesar dengan Pembelajaran online adalah karena ketidakstabilan Jaringan, Dan Siswa mengalami kesulitan Jaringan yang mengakibatkan terganggunya pembelajaran di kelas online mereka. Jaringan merupakan faktor penting bagi lingkungan pembelajaran on-line. Mayoritas siswa membahas tentang jaringan internet sebagai pelayanan ruang kelas pembelajaran on-line, sebagai pertimbangan yang penting. Dalam pembelajaran jarak jauh jaringan tidak hanya merupakan metode

\footnotetext{
${ }^{16}$ Ahmad Idzhar,.. Peranan Guru Dalam Meningkatkan Motivasi Belajar Siswa. Jurnal office. (Banteang: SMK Negeri 1 Banteang,2016). Vol.2 No.2
} 
untuk mempelajari materi pendidikan, tetapi juga sarana untuk mengukur antara guru dan siswa atau di antara siswa (Trentin, 2007) ${ }^{17}$. Ketidakpuasan dengan interaksi termasuk komunikasi dengan guru serta pembubaran langsung hubungan antara sekelas dan kurangnya aturan umpan balik dapat ditukar antara siswa.Menurut Tu dan McIsaac (2002), komunikasi on-line bervariasi sesuai dengan keterampilan siswa, karena komunikasi yang tepat sulit dilakukan jika keterampilan siswa tidak mencukupi, guru harus memahami tingkat keterampilan siswa. Persepsi respons syring mencakup memuaskan dan tidak memuaskan dalam proses menerima pembelajaran jarak jauh. Hasil ini menunjukkan bahwa interaksi secara langsung melibatkan lebih banyak orang yang terhubung terhadap masing-masing siswa dibandingkan dengan sistem pribadi jarak jauh. Guru dan siswa dapat diandalkan hanya ketika mereka melaksanakannya, untuk belajar fungsi platform online dengan lancar dan aktif, agar menginvestasikan waktu dalam komunikasi. ${ }^{18}$

\section{KESIMPULAN DAN SARAN}

Kesimpulan yang dapat diambil dari penelitian ini adalah dimana peran guru terhadap motivasi belajar siswa sangat berpengaruh, dimana strategi pembelajaran yang efektif dalam sistem pembelajaran online ini dapat menghasilkan respons energi prestasi yang baik bagi siswa. Berkurangnya minat siswa terhadap pembelajaran sistem online ini pada dasarnya dikarenakan oleh berbagai faktor umum seperti fasilitas pembelajaran hingga sulitnya akses guru dan siswa untuk melakukan pembelajaran sisitem online. Keinginan siswa untuk berinteraksi secara langsung dalam pembelajaran sangat sulit dikarenakan kondisi saat ini, maka di harapkan bagi guru dapat melakukan sikap profesional sebagai pendidik agar dapat memproses pembelajaran sehingga dapat mencapai kepuasan bagi siswa dalam mengikuti pembelajaran sistem online ini.

Berdasarkan kesimpulan diatas maka dapat disarankan bahwa pembelajaran pada sistem online sikap guru sangat penting dan di butuhkan untuk tercapainya pembelajaran secara efektif. Dalam meningkatkan minat belajar siswa motivasi dari guru sangat di butuhkan untuk meningkatkan hasil prestasi siswa. Sebaiknya dalam pembelajaran online guru dapat menyusun strategi pembelajaran yang efektif dan kreatif sehingga siswa mudah dalam memahami materi yang disampaikan oleh guru.

\footnotetext{
${ }^{17}$ Guglielmo Trentin,.. A Multidimensional Approach to E-Learning Sustainability. (Italian National Research Council,2007).

${ }^{18} \mathrm{Tu}, \mathrm{C} . \mathrm{H} .$, \& McIsaac, M. 2002. The Relationship of social presence and interaction in online classes. The American Journal of Distance Education, 16(3), 131-150
} 


\section{DAFTAR PUSTAKA}

A. M.,Sardiman. (1986). Interaksi dan Motivasi Belajar dan Mengajar. Jakarta: Raja Grafindo Persada

Ali, M. 1983. Guru dalam Proses Belajar Mengajar. Bandung: Sinar Baru Algesindo.

Azwar, Saifuddin. 2010. Metode Penelitian. Yogyakarta: Pustaka Pelajar.

Bougie, dan Sekaren. 2013. Edisi 5, Research Metodhs For Business: A Skill Building Approach. New York: John wiley@Sons.

Buchori, M. 1983. Tehnik-Tehnik Evaluasi Dalam Pendidikan. Jakarta: Jakarta Djambatan.

E. Mulyasa. 2013. Pengembangan dan Implementasi Kurikulum 2013. Bandung: PT. Rosda Karya.

Fauzi, Imron. 2017. Etika Profesi keguruan. Jember:IAIN Press.

Idzhar, Ahmad. 2016. Peranan Guru Dalam Meningkatkan Motivasi Belajar Siswa. Jurnal office. Banteang: SMK Negeri 1 Banteang. Vol.2 No.2

Lee J, Conbach. 1954. Educational Psychology. New York: HARCOURT, BRACE AND COMPANY.

Muhibbin, Syah. 1995. Psikologi Pendidikan . Bandung: Remadja Rosda Karya.

Purwanto Agus, Masduki Asbari, Mochammad Fahlevi, Abdul Mufid, Eva Agistiawati, Yoyok Cahyono, Popong Suryani. (2020). Impact of Work From Home (WFH) on Indonesian Teachers Performance During the Covid-19 Pandemic : An Exploratory Study. International Journal of Advanced Science and Technology, 29(05), 6235 6244.

Suryana, Dadan. 2013. Pengetahuan Tentang Strategi Pembelajaran, Sikap, Dan Motivasi Guru. Jurnal Ilmu Pendidikan. Padang: Universitas Negeri Padang. Jilid 19. No. 2.

Trentin, Guglielmo. 2007. A Multidimensional Approach to E-Learning Sustainability. Italian National Research Council.

Tu, C. H., \& McIsaac, M. 2002. The Relationship of social presence and interaction in online classes. The American Journal of Distance Education, 16(3), 131-150

Winkel, W.S. 1989. Psikologi Penddidikan dan Evaluasi Belajar. Jakarta: Gramedia. 